\title{
PERBAIKAN KARAKTERISTIK KAYU KELAPA HIBRIDA MELALUI METODE PEMANASAN DAN PEMADATAN
}

\author{
The Improvement of Coconut Wood Characteristics Using Heating and Densification Methods
}

Suhasman, Sucahyo Sadiyo, dan Zahrial Coto

\begin{abstract}
For optimum utilization of coconut wood, there are necessity to improve the quality of the wood caused by higroscopicity, low dimensional stability, and extreme variability of dimension in lateral direction. The purpose of the research were to analyze the characteristics of coconut wood that had been treated by heating and densification. The treatment consist of one or two hours heating, one hour heating combined to 10 or $20 \%$ densification, two hours heating combined to 10 or $20 \%$ densification. Temperature that applied for all specimen were $180^{\circ} \mathrm{C}$. The research results are as follows: (1) Heating treatment combined to densification effective to reduce higroscopicity of coconut wood, (2) Heating treatment for two hours are suffice as pretreatment to densify the soft part of coconut wood for $20 \%$, (3) Dimensional stability of coconut wood may improve using heating combined to densification treatments that indicated by decreasing rate of dimensional change, (4) Heating and densification treatment effective to improve the hardness of soft part coconut wood.
\end{abstract}

Keywords : coconut wood, heating treatment, densification

\section{PENDAHULUAN}

Seperti jenis-jenis kayu pada umumnya, sifat higroskopis dan perubahan dimensi akibat penyerapan dan pelepasan uap air pada kayu kelapa juga merupakan salah satu kelemahan pada jenis bahan ini. Tidak hanya itu, perubahan kadar air juga dapat mempengaruhi sifat mekanis, karena secara umum, peningkatan kadar air akan menurunkan kekuatan dan kekakuan kayu.

Selain kelemahan di atas, kayu kelapa juga memiliki kelemahan lain yaitu perbedaan sifat-sifat fisik dan mekanisnya sangat ekstrim pada arah lateral. Penelitian Wardhani et al. (2006) menunjukkan bahwa kerapatan kayu kelapa bagian luar adalah $0,85 \mathrm{~g} / \mathrm{cm}^{3}$, sementara bagian tengahnya hanya $0,42 \mathrm{~g} / \mathrm{cm}^{3}$. Adapun keteguhan patahnya berkisar antara $920-1409 \mathrm{~kg} / \mathrm{cm}^{2}$ untuk bagian luar dan $475-759 \mathrm{~kg} / \mathrm{cm}^{2}$ untuk bagian tengah (Departemen Perindustrian, 1986). Dengan karakteristik demikian maka diperlukan upayaupaya peningkatan kualitas kayu kelapa bagian lunak atau bagian tengah agar pemanfaatannya sebagai bahan substitusi kayu dari hutan alam dapat dioptimalkan.

Usaha-usaha perbaikan kualitas kayu dapat dilakukan melalui berbagai cara seperti modifikasi kimia, perlakuan pemanasan, dan pemadatan. Dibandingkan dengan modifikasi kimia, perbaikan kualitas kayu melalui perlakuan pemanasan dan pemadatan memiliki keuntungan karena terbebas dari bahan kimia yang potensial menimbulkan dampak lingkungan. Perlakuan pemanasan biasanya dilakukan pada kisaran suhu $180{ }^{\circ} \mathrm{C}-260$ ${ }^{\circ} \mathrm{C}$. Suhu di bawah $140{ }^{\circ} \mathrm{C}$ hanya menghasilkan sedikit perubahan sifat-sifat kayu, sementara suhu di atas $260^{\circ} \mathrm{C}$ menyebabkan degradasi substrat kayu secara nyata (Hill, 2006). Perlakuan panas menunjukkan perbaikan sifat fisis dan kekerasan kayu, akan tetapi di sisi lain peningkatan keteguhan lentur hanya mencapai titik optimal pada suhu $160{ }^{\circ} \mathrm{C}$, dan setelahnya mengalami penurunan (Finnish Thermowood Association 2003). Hal yang sama juga dikemukakan oleh Militz dan Tjeerdsma (2007), yang menyatakan bahwa kekuatan kayu menurun pada kisaran 5$18 \%$ akibat perlakuan pemanasan.

Peningkatan kualitas kayu melalui teknologi pemadatan antara lain telah diteliti oleh Inoue et al. (1993). la menyatakan bahwa pemadatan kayu pada arah radial efektif untuk meningkatkan sifat mekanis dan kehalusan permukaan kayu. Masalah yang sering dihadapi adalah rendahnya stabilitas dimensi ketika suhu yang diaplikasikan pada saat 
densifikasi di bawah $100^{\circ} \mathrm{C}$ (Dwianto et al., 1999). Proses pemadatan kayu dilakukan melalui pelunakan komponen penyusun kayu. Pelunakan ini dapat dicapai melalui perlakuan pemanasan kayu pada kadar air di atas titik jenuh serat (Norimoto dan Gril, 1989), maupun dengan pemanasan pada kondisi kadar air di bawah titik jenuh serat pada suhu di atas titik transisi glass lignin dan hemisellulosa (Kelly et al. 1987) dalam Srinivasan et al. (2006).

Berdasarkan uraian di atas, maka penelitian dilaksanakan untuk menganalisis kemungkinan upaya perbaikan karakteristik kayu kelapa hibrida bagian lunak melalui perlakuan pemanasan dan pemadatan.

\section{BAHAN DAN METODE}

\section{Persiapan Bahan}

Bahan penelitian ini adalah kayu kelapa hibrida dalam bentuk sortimen papan dengan ukuran tebal antara 2,0-3,5 cm, lebar bagian ujung dan pangkal sangat bervariasi dari $20-40 \mathrm{~cm}$ serta panjang sekitar $100 \mathrm{~cm}$. Sortimen papan berasal dari berbagai ketinggian pohon mulai dari bagian pangkal sampai dengan bagian ujung. Pada percobaan ini digunakan pula bahan lain seperti larutan $\mathrm{H}_{2} \mathrm{SO}_{4}$ pekat (teknis).

Sortimen kayu kelapa dipotong menjadi contoh uji dengan ukuran penampang $2 \times 6 \mathrm{~cm}$ dan panjang $20 \mathrm{~cm}$. Contoh uji diperoleh dari bagian tengah kayu kelapa, yaitu sekitar $3 \mathrm{~cm}$ atau lebih dari bagian tepi. Sebagai pembanding, digunakan bagian keras yang diperoleh dari bagian tepi kayu kelapa.

Prosedur penelitian perbaikan karakteristik kayu kelapa ini dilakukan sebagai berikut :

1. Seluruh contoh uji dimasukkan ke dalam oven temperatur $50{ }^{\circ} \mathrm{C}$ selama 2 (dua) hari, kemudian dipindahkan ke dalam oven temperatur $103^{\circ} \pm 2^{\circ} \mathrm{C}$ sampai mencapai berat konstan.

2. Contoh uji dikeluarkan dari oven kemudian ditimbang beratnya $\left(B_{K T 1}\right)$ dan diukur dimensi tebal $\left(\mathrm{T}_{\mathrm{K} T 1}\right)$, lebar $\left(\mathrm{L}_{\mathrm{KT} 1}\right)$ dan panjang $\left(\mathrm{P}_{\mathrm{KT} 1}\right)$.

3. Contoh uji dimasukkan ke dalam oven pada temperatur $180{ }^{\circ} \mathrm{C}$ selama 1 atau 2 jam $(P)$, kemudian langsung dilakukan pengempaan selama 5 menit pada suhu $180{ }^{\circ} \mathrm{C}$ untuk mencapai pengurangan tebal $10 \%$ atau $20 \%$ dari tebal awalnya. Secara keseluruhan, kombinasi perlakuan yang dicobakan dalam penelitian ini adalah :

(a) Kayu kelapa keras tanpa perlakuan (KK)

(b) Kayu kelapa lunak tanpa perlakuan (KL)

(c) Kayu kelapa lunak dengan perlakuan pemanasan selama 1 jam (P1)

(d) Kayu kelapa lunak dengan perlakuan pemanasan selama 2 jam (P2)

(e) Kayu kelapa lunak dengan perlakuan pemanasan selama 1 jam dan dikempa sampai mengalami pengurangan tebal $10 \%$ dari tebal awal (P1K10)

(f) Kayu kelapa lunak dengan perlakuan pemanasan selama 1 jam dan dikempa sampai mengalami pengurangan tebal $20 \%$ dari tebal awal (P1K20)

(g) Kayu kelapa lunak dengan perlakuan pemanasan selama 2 jam dan dikempa sampai mengalami pengurangan tebal $10 \%$ dari tebal awal (P2K10)

(h) Kayu kelapa lunak dengan perlakuan pemanasan selama 2 jam dan dikempa sampai mengalami pengurangan tebal $20 \%$ dari tebal awal (P2K20)

Masing-masing perlakuan tersebut dilakukan dengan tiga kali ulangan sehingga secara keseluruhan contoh uji yang digunakan sebanyak 24 buah.

4. Contoh uji yang telah diberi perlakuan pemanasan dan pengempaan dibiarkan pada kondisi ruang selama 1 (satu) minggu kemudian ditimbang beratnya $\left(B_{K u}\right)$ dan diukur dimensi tebal $\left(T_{K u}\right)$ dan lebarnya $\left(L_{K u}\right)$.

5. Selanjutnya contoh uji dimasukkan ke dalam kotak akuarium berkelembaban rendah (RH $50 \%$ ) selama 1 (satu) minggu dan ditimbang beratnya $\left(B_{50 \%}\right)$ serta diukur dimensi tebal $\left(\mathrm{T}_{50 \%}\right)$ dan lebarnya $\left(\mathrm{L}_{50 \%}\right)$.

6. Seluruh contoh uji diuji kekerasan permukaannya menggunakan UTM Amsler (Krs).

7. Seluruh contoh uji dikeringkan kembali dalam oven temperatur $103 \pm 2{ }^{\circ} \mathrm{C}$ sampai mencapai berat konstan $\left(\mathrm{BKT}_{2}\right)$. Selanjutnya diukur dimensi tebal $\left(T_{K T 2}\right)$ dan lebarnya $\left(L_{K T 2}\right)$.

Rumus-rumus yang digunakan untuk menghitung beberapa parameter penting adalah :

1. Kerapatan $\mathrm{KU}=\mathrm{B}_{\mathrm{KU}} / N_{\mathrm{KU}}\left(\mathrm{g} / \mathrm{cm}^{3}\right)$

2. Kerapatan KU-Perl. = $B_{K U}$ Perlakuan $/ V_{K U}$ Perlakuan $\left(\mathrm{g} / \mathrm{cm}^{3}\right)$ 
3. Kerapatan $\mathrm{RH} 50 \%=\mathrm{B}_{\mathrm{KU}} 50 \% / \mathrm{N}_{\mathrm{KU}} 50 \%\left(\mathrm{~g} / \mathrm{cm}^{3}\right)$

4. Pengurangan Tebal-KU $\left(\mathrm{DT}_{\mathrm{KU}}\right)=\left\{\left(\mathrm{T}_{\mathrm{KU}}\right.\right.$ $\left.\left.T_{\text {KUper. } .}\right) / T_{\text {Ku }}\right\} \times 100 \%$

5. Pengurangan Tebal- RH 50\% (DT $50 \%)=\left\{T_{K U}\right.$ $\left.T_{50 \%} / / T_{K u}\right\} \times 100 \%$

6. Kadar air $\mathrm{KU}\left(\mathrm{K} A_{K U}\right)=\left\{\left(B_{K U}-B_{K T}\right) / B_{K T}\right\} \times 100 \%$

7. Kadar air $K U_{\text {perl. }}\left(K A_{\text {KUperl. }}\right)=\left\{\left(B_{\text {KUperl. }}\right.\right.$ $\left.\mathrm{B}_{K T} \mathrm{~T} / \mathrm{B}_{\mathrm{KT}}\right\} \times 100 \%$

8. Kadar air $\mathrm{RH} \quad 50 \% \quad\left(\mathrm{KA}_{50 \%}\right)=\left\{\left(\mathrm{B}_{50 \%-}\right.\right.$ $\left.B_{K T} / B_{K T}\right\} \times 100 \%$

9. Perubahan KA KU-RH $50 \%=\left(K_{K U^{-}}\right.$ $\left.\mathrm{KA}_{50 \%}\right) \times 100 \%$

10. Penyusutan Tebal KU-RH 50\% (ST) $=\mathrm{DT}_{\mathrm{KU}}$ $\mathrm{DT}_{50 \%}$

11. Penyusutan Lebar KU-RH $50 \%(\mathrm{SL})=\mathrm{DL}_{\mathrm{KU}}$ $\mathrm{DL} 50 \%$

12. Penyusutan Tebal per $1 \% \mathrm{KA}=(\mathrm{ST}) /\left(\mathrm{KA} \mathrm{KU}^{-}\right.$ $\mathrm{KA}_{50 \%}$ )

13. Penyusutan Lebar per $1 \% \mathrm{KA}=(\mathrm{SL}) /\left(\mathrm{KA} \mathrm{KU}_{\mathrm{U}}\right.$ $K A_{50 \%}$ )

14. Kekerasan $=P / A\left(\mathrm{~kg} / \mathrm{cm}^{2}\right)$

15. Perubahan $B K T=\left(B K T_{\text {sebelum perlakuan }}-B K T_{\text {setelah }}\right.$ perlakuan $\left./ B K T_{\text {sebelum perlakuan }}\right) \times 100 \%$

Data-data yang diperoleh dari hasil pengujian diolah dan dianalisis secara deskriptif dengan tampilan dalam bentuk tabel rata-rata atau histogram untuk melihat perbedaan antara satu perlakuan dengan perlakuan lainnya.

\section{HASIL DAN PEMBAHASAN}

\section{Sifat Fisik}

\section{Kerapatan}

Sebelum diberi perlakuan panas pada temperatur $180^{\circ} \mathrm{C}$ kerapatan contoh uji kayu kelapa hibrida bagian lunak berkisar antara 0,37-0,50 $\mathrm{g} / \mathrm{cm}^{3}$, sementara bagian kerasnya adalah 0,75 $\mathrm{g} / \mathrm{cm}^{3}$. Kayu yang mengalami perlakuan pemanasan tanpa pemadatan cenderung mengalami penurunan kerapatan, sementara kayu yang mengalami perlakuan pemanasan dan pemadatan mengalami fenomena yang berbedabeda. Kayu yang dipanasi 2 jam dan dikempa 20\% mengalami peningkatan kerapatan, sementara yang lainnya cenderung tetap atau sedikit menurun. Tampaknya, fenomena ini disebabkan oleh tidak tercapainya target pengempaan yang diinginkan pada perlakuan lainnya. Kerapatan contoh uji hasil perlakuan pada kondisi ruang berkisar antara 0,38-0,49 $\mathrm{g} / \mathrm{cm}^{3}$ sementara pada RH 50\% berkisar antara 0,37-0,47 g/cm (Tabel 1). Sebagaimana disajikan pada Tabel 1, perlakuan pemadatan ternyata belum mampu mendekati kerapatan bagian keras kayu kelapa. Tingginya perbedaan kerapatan antara bagian keras dan bagian lunak kayu kelapa disebabkan oleh proporsi vascular bundle yang terdapat pada bagian kayu keras jauh lebih besar dibandingkan bagian lunaknya. Vascular bundle diketahui memiliki peranan penting dalam kepadatan kayu kelapa.

Data pada Tabel 1 menunjukkan perbedaan kerapatan yang tidak signifikan setelah contoh uji diberi perlakuan panas. Pemberian panas pada temperatur $180{ }^{\circ} \mathrm{C}$ selama 1 atau 2 jam dapat melunakkan lignin dan mendegradasi hemiselulosa namun tidak cukup berarti dalam mengurangi atau menurunkan berat contoh uji. Demikian halnya dengan pemberian tekanan atau pemadatan pada permukaan sebesar $10 \%$ dari tebal total contoh uji dapat menurunkan volume tetapi penurunan tersebut belum signifikan. Dari seluruh contoh uji yang diberi perlakuan pemanasan dan pemadatan, hanya contoh uji yang dipanaskan 2 jam dan dipadatkan 20\% yang mengalami peningkatan

Table 1. Mean values of air dry density, air dry density after treatment, and $\mathrm{RH} 50 \%$ density after treatment of hybrid coconut wood densification with heating under various treatments

\begin{tabular}{cccc}
\hline Treatments & $\begin{array}{c}\text { Air dry density } \\
\left(\mathrm{g} / \mathrm{cm}^{3}\right)\end{array}$ & $\begin{array}{c}\text { Air dry density of } \\
\text { treatment }\left(\mathrm{g} / \mathrm{cm}^{3}\right)\end{array}$ & $\begin{array}{c}\text { RH 50\% density of } \\
\text { treatment }\left(\mathrm{g} / \mathrm{cm}^{3}\right)\end{array}$ \\
\hline KOK & 0,75 & 0,74 & 0,72 \\
KOL & 0,50 & 0,47 & 0,46 \\
P1L & 0,41 & 0,39 & 0,38 \\
P2L & 0,49 & 0,47 & 0,46 \\
P1K10L & 0,38 & 0,38 & 0,37 \\
P1K20L & 0,44 & 0,45 & 0,44 \\
P2K10L & 0,49 & 0,49 & 0,47 \\
P2K2OL & 0,37 & 0,42 & 0,40 \\
\hline
\end{tabular}


Table 2. Mean values of moisture content of hybrid coconut wood densification with heating under various treatments

\begin{tabular}{cccc}
\hline Treatments & Initial air dry moisture (\%) & $\begin{array}{c}\text { Air dry moisture content } \\
\text { after treatments (\%) }\end{array}$ & $\begin{array}{c}\text { RH 50\% moisture content } \\
\text { after treatments (\%) }\end{array}$ \\
\hline KOK & 17,14 & 10,34 & 4,29 \\
KOL & 17,94 & 11,48 & 4,39 \\
P1L & 18,34 & 11,68 & 3,43 \\
P2L & 17,80 & 11,46 & 2,76 \\
P1K10L & 20,43 & 9,50 & 4,29 \\
P1K20L & 17.63 & 9,31 & 4,39 \\
P2K10L & 20,03 & 8,16 & 3,01 \\
P2K20L & 18,57 & 6,66 & 0,95 \\
\hline
\end{tabular}

kerapatan yang cukup berarti. Hal tersebut menunjukkan bahwa hanya kombinasi perlakuan tersebut yang cukup memadai untuk meningkatkan kerapatan papan.

\section{Kadar air}

Sebelum diberi perlakuan panas pada temperatur $180{ }^{\circ} \mathrm{C}$ kadar air kering udara atau kadar air keseimbangan (KAK) awal seluruh contoh uji berkisar antara 17,14-20,43\%. Rataan KAK contoh uji sebelum dan setelah mengalami perlakuan disajikan pada Tabel 2.

Pada kondisi KA-KU terdapat kecenderungan bahwa bagian lunak memiliki KAK lebih tinggi dibandingkan dengan bagian keras kayu kelapa hibrida. Hal ini disebabkan bagian kayu lunak banyak mengandung pati atau gula-gula sederhana yang bersifat menyerap uap lembab dibandingkan dengan bagian kayu kerasnya. Namun demikian, fenomena ini tidak terjadi pada KAK RH 50\%, di mana hampir seluruh KAK kayu lunak justru lebih rendah dari kayu keras. Terjadi penurunan KAK secara signifikan setelah seluruh contoh uji diberi perlakuan panas $180{ }^{\circ} \mathrm{C}$. Penurunan KAK karena pemberian panas kemungkinan disebabkan oleh penurunan jumlah gugus $\mathrm{OH}$ bebas yang berubah menjadi ikatan silang (cross linking) antar 2 atau lebih gugus $\mathrm{OH}$. Gugus $\mathrm{OH}$ bebas bertanggung jawab terhadap absorpsi uap air dari lingkungan udara di sekitarnya. Dengan menurunnya jumlah gugus $\mathrm{OH}$ bebas, maka kemampuan mengabsorpsi uap lembab juga menurun. Data pada Tabel 2 juga menunjukkan bahwa KAK kontrol yang hanya dikeringkan pada suhu $103^{\circ} \mathrm{C}$ relatif sama dengan KAK kayu yang mengalami perlakuan pemanasan tanpa pemadatan pada kondisi kering udara. Hal tersebut mengindikasikan bahwa perlakuan pemanasan tanpa pemadatan dalam percobaan ini belum cukup mampu mereduksi KAK.

Rataan kadar air contoh uji setelah diberi panas dan dikondisikan masing-masing dalam suhu kamar (udara terbuka) antara 6,66-11,68\% dan ruang dengan $\mathrm{RH} 50 \%$ berkisar antara 0,95$4,39 \%$. Terdapat penurunan kadar air keseimbangan (KAK) secara signifikan setelah dikondisikan dari ruang udara terbuka ke ruang dengan $\mathrm{RH}$ $50 \%$. KA-KU perlakuan lebih tinggi dibandingkan KAK RH 50\% untuk semua perlakuan. Perbedaan KAK ini disebabkan aplikasi panas mengakibatkan terjadi perubahan respon kayu terhadap kadar air, yaitu berupa penurunan KAK pada $\mathrm{RH}$ tertentu. Telah dibuktikan bahwa pemberian panas di atas $100{ }^{\circ} \mathrm{C}$ menyebabkan penurunan kadar air keseimbangan kayu sangat signifikan. Pada saat kayu dimasukkan ke dalam ruangan $\mathrm{RH} 50 \%$ terjadi lagi penurunan KAK untuk menyesuaikan dengan kondisi lingkungan sekitarnya. Pada saat tersebut diduga terjadi lagi ikatan silang antar 2 atau lebih gugus hidroksil sehingga higroskopisitas kayu menurun atau kemampuan untuk mengabsorpsi uap lembab menjadi rendah.

\section{Penyusutan dimensi}

Pengurangan tebal contoh uji setelah diberi perlakuan panas dan dikondisikan masing-masing dalam suhu kamar (udara terbuka) dari $-0,19 \%$ sampai dengan $18,73 \%$ dan pada kondisi $\mathrm{RH} 50 \%$ berkisar antara 2,41-20,29\%. Penyusutan dimensi dari kondisi kering udara ke $\mathrm{RH} 50 \%$ masingmasing untuk dimensi lebar $0,81-1,55 \%$ dan dimensi tebal 0,76-2,81\%. Besarnya susut per perubahan $1 \%$ kadar air untuk dimensi lebar berkisar antara 0,11-0,26 dan dimensi tebal dari 
Table 3. Mean values of thick reduction and shrinkage of hybrid coconut wood densification with heating under various treatments

\begin{tabular}{|c|c|c|c|c|c|c|}
\hline \multirow[t]{2}{*}{ Treatments } & \multirow{2}{*}{$\begin{array}{l}\text { Thick reduction } \\
\text { (air dry condition) }\end{array}$} & \multirow{2}{*}{$\begin{array}{c}\text { Thick reduction } \\
\text { (RH 50\% } \\
\text { condition) }\end{array}$} & \multicolumn{2}{|c|}{$\begin{array}{c}\text { Shrinkage } \\
\text { Air dry-RH } 50 \%\end{array}$} & \multicolumn{2}{|c|}{ Shrinkage / $\triangle K A$} \\
\hline & & & width & thickness & width & thickness \\
\hline KOK & 1,01 & 3,33 & 1,55 & 2,33 & 0,26 & 0,39 \\
\hline $\mathrm{KOL}$ & $-0,19$ & 2,62 & 1,25 & 2,81 & 0,17 & 0,38 \\
\hline P1L & 0,51 & 2,41 & 1,19 & 1,91 & 0,16 & 0,26 \\
\hline P2L & 0,70 & 2,45 & 1,21 & 1,76 & 0,17 & 0,25 \\
\hline P1K10L & 7,88 & 9,83 & 0,99 & 2,12 & 0,16 & 0,34 \\
\hline P1K20L & 8,95 & 10,67 & 1,06 & 1,90 & 0,17 & 0,30 \\
\hline P2K10L & 8,11 & 9,73 & 1,27 & 1,76 & 0,21 & 0,29 \\
\hline P2K20L & 18,73 & 20,29 & 0,81 & 1,91 & 0,11 & 0,24 \\
\hline
\end{tabular}

0,24-0,39. Data secara rinci dari masing-masing perlakuan disajikan pada Tabel 3. Seluruh contoh uji yang diberi perlakuan panas selama 1 atau 2 jam hampir mencapai tebal target dan setelah dikondisikan tetap stabil ukuran tebalnya. Beberapa contoh uji dengan pemanasan 2 jam dan dikempa 20\% mengalami kerusakan di bagian tepi pada arah lebarnya. Di samping tekanan yang memadai, pemberian panas selama 2 jam dianggap telah berhasil melunakkan lignin untuk seluruh ketebalan contoh uji (maksimum $2 \mathrm{~cm}$ ), sehingga terjadi pergeseran atau perpindahan lignin mengisi bagian-bagian lubang mikro (mikroporous) untuk selanjutnya mengeras kembali setelah mencapai suhu kamar. Fenomena tersebut menyebabkan dimensi tebal tetap bertahan pada ukuran tebal target. Namun pada pemanasan 1 jam, pemadatan untuk mencapai penurunan tebal sasaran $20 \% \quad\left(P_{1} K_{20} L\right)$ fenomenanya agak berbeda, dimana pada bagian tengah tebal papan, lignin belum seluruhnya melunak (lumer) sehingga setelah mencapai suhu kamar, target tebal sasaran tidak atau belum mencapai setengah dari target yang direncanakan $(20 \%)$.

Terdapat kecenderungan perubahan dimensi ke arah tebal lebih besar dibandingkan dengan ke arah lebar untuk seluruh contoh uji. Contoh uji yang tidak diberi pengempaan, termasuk kontrol, susutnya lebih besar dibandingkan dengan contoh uji yang dikempa. Fenomena tersebut disebabkan contoh uji yang telah diberi perlakuan panas dan dikondisikan mengalami penurunan sifat higroskopisitas sehingga meningkatkan kestabilan dimensi.

\section{Laju Perubahan Dimensi}

Setelah diberi panas dan dikondisikan dalam suhu kamar (udara terbuka) dan ruang dengan $\mathrm{RH}$ $50 \%$, terdapat kecenderungan penurunan laju perubahan dimensi pada contoh uji yang diberi perlakuan pemanasan, maupun pemanasan dan pemadatan, dibandingkan dengan bagian lunak

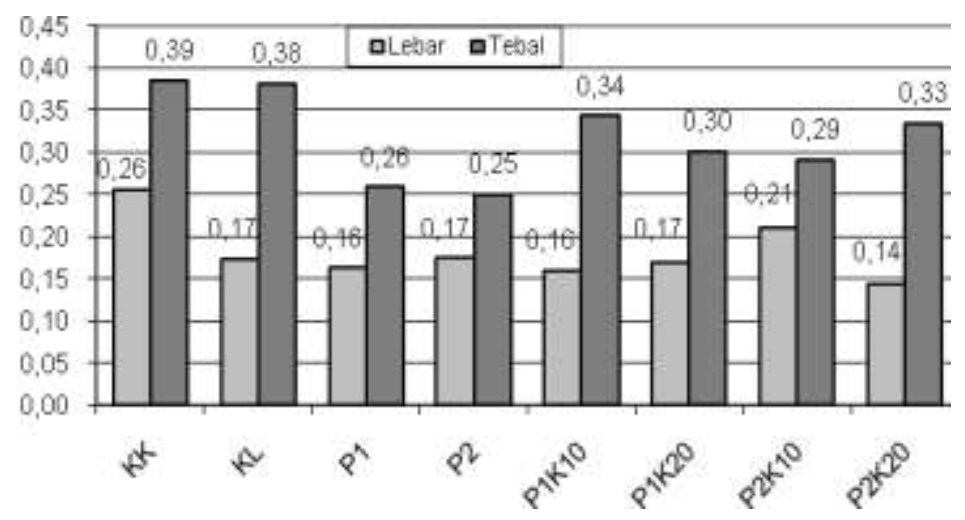

Figure 1. Rate of thick and width dimensional changes of hybrid coconut wood under various treatments 


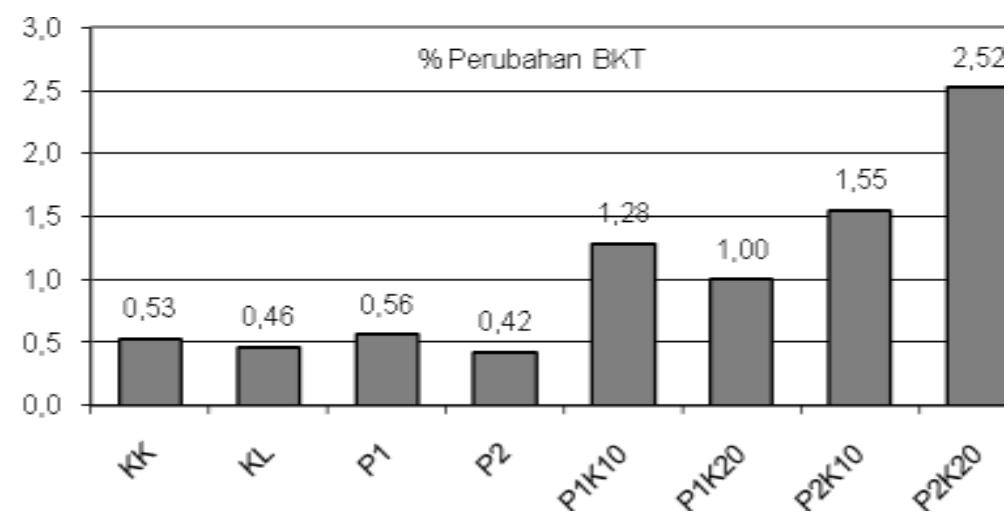

Figure 2. Percentage of oven dry weight changes of hybrid coconut wood under various treatments.

maupun bagian keras kayu kelapa tanpa perlakuan. Laju perubahan dimensi yang menyatakan besarnya perubahan penyusutan dimensi per satuan perubahan kadar air memperlihatkan bahwa laju perubahan dimensi lebar lebih kecil dibandingkan dengan dimensi tebal untuk seluruh contoh uji (Gambar 1). Pada konteks ini, rataan laju pengurangan dimensi dari kondisi kering udara ke $\mathrm{RH} 50 \%$ masing-masing untuk dimensi lebar 0,10-0,26 dan dimensi tebal berkisar 0,25-0,39 (Tabel 3). Histogram pada Gambar 1 juga menunjukkan nilai laju perubahan dimensi perlakuan yang cenderung lebih kecil dibandingkan dengan bagian keras dan bagian lunak kayu kelapa tanpa perlakuan. Hal ini mengindikasikan bahwa perlakuan pemanasan maupun pemadatan mampu menurunkan higroskopisitas bahan.

\section{Perubahan Berat Kering Tanur}

Perubahan berat kering tanur (BKT) diperoleh dari selisih antara berat kering tanur sebelum perlakuan pemanasan dan pemadatan dengan setelah perlakuan. Hasil perhitungan menunjukkan bahwa terdapat penurunan BKT setelah bahan mengalami perlakuan. Hal tersebut mengindikasikan bahwa terjadi degradasi sebagian komponen kayu selama perlakuan. Hal ini terutama terjadi pada bahan-bahan volatil dalam kayu serta sebagian komponen hemiselulosa. Terlihat bahwa contoh uji yang mengalami pemanasan lebih lama (2 jam) mengalami penurunan berat yang lebih tinggi yang ditunjukkan oleh besarnya persentase perubahan BKT.

\section{Sifat Mekanis}

Sifat mekanis yang diuji dalam penelitian ini adalah kekerasan kayu. Rataan kekerasan kayu berkisar antara 163-387 kg/cm². Beberapa penelitian menunjukkan bahwa secara umum kekuatan kayu bagian tepi (keras) lebih tinggi dibandingkan bagian tengah (lunak) batang kelapa, termasuk kelapa hibrida. Perbedaan kekuatan atau kekerasan ini sejalan dengan proporsi kandungan vascular bundle-nya, dimana jumlahnya jauh lebih besar pada bagian tepi dibandingkan dengan bagian tengahnya. Pernyataan lainnya menyebutkan bahwa makin tinggi kerapatan kayu maka makin tinggi pula kekuatan atau kekakuan kayu tersebut.

Terdapat variasi kekerasan yang cukup besar pada kayu kelapa hibrida yang telah diberi perlakuan panas dan pemadatan. Perbedaan ini terutama lebih disebabkan oleh asal contoh uji yang kurang dapat ditelusuri menurut letak posisi ketinggian batang. Pengambilan dan penentuan contoh uji bagian keras atau lunak ditetapkan secara acak dari kumpulan sortimen kayu kelapa yang berasal dari berbagai ketinggian pohon. Padahal diketahui pula bahwa bagian pangkal lebih kuat atau lebih keras dibandingkan bagian atas batang kelapa.

Terdapat kecenderungan bahwa perlakuan pemanasan selama 1 atau 2 jam menghasilkan kekerasan yang relatif sama pada tingkat pengempaan $20 \%$. Pada konteks ini, hemiselulosa membentuk ikatan hidrogen dengan permukaan mikrofibril dan berikatan kovalen dengan matrik 


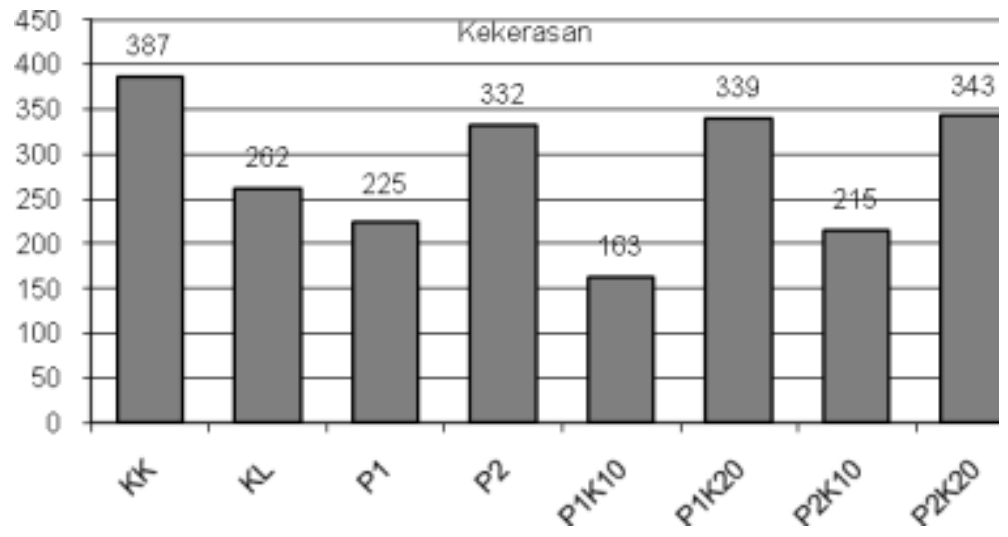

Figure 3. Surface hardness of hybrid coconut wood under various treatments.

lignin (Koshijima \& Watanabe 2003). Lignin juga turut berperan, karena meskipun relatif kaku pada suhu kamar namun akan melunak pada suhu sekitar $140{ }^{\circ} \mathrm{C}$ dan kehadiran uap air di dalam dinding sel berguna sebagai plasticizer lignin. Dari data yang disajikan pada Gambar 3 diketahui bahwa perlakuan pemadatan $20 \%$ telah mampu meningkatkan kekerasan bagian lunak kayu kelapa sampai mendekati kekerasan bagian kerasnya. Fenomena ini mengindikasikan bahwa aplikasi metode pemanasan dan pemadatan ini telah mampu memperbaiki sifat kekerasan bagian lunak kayu kelapa.

\section{KESIMPULAN}

Berdasarkan hasil penelitian ini dapat disimpulkan bahwa:

1. Perlakuan pemanasan dan pemadatan efektif dalam menurunkan sifat higroskopisitas kayu yang ditunjukkan oleh kadar air keseimbangan kayu yang rendah, sementara perlakuan pemanasan tanpa pemadatan memiliki kadar air keseimbangan yang relatif sama dengan kontrol.

2. Perlakuan pemanasan pada suhu $180{ }^{\circ} \mathrm{C}$ selama 2 jam cukup memadai untuk digunakan sebagai perlakuan pendahuluan untuk melakukan pemadatan bagian lunak kayu kelapa sampai mencapai pengurangan tebal $20 \%$, sementara pemanasan selama 1 jam belum cukup memadai.

3. Stabilitas dimensi kayu kelapa dapat diperbaiki dengan pemberian kombinasi perlakuan pemanasan dan pemadatan yang ditandai oleh penurunan laju perubahan dimensi pada contoh uji yang diberi kombinasi perlakuan tersebut.

4. Perlakuan pemanasan dan pemadatan cukup efektif meningkatkan kekerasan bagian lunak kayu kelapa, khususnya pada pemadatan $20 \%$ dari ketebalan awalnya.

\section{DAFTAR PUSTAKA}

Departemen Perindustrian, 1986. Penentuan Proporsional Batang Kelapa untuk Maksimal Penggunaannya sebagai Subtitusi Bahan Kayu. Badan Penelitian dan Pengembangan Industri. Banjar Baru

Dwianto, W., T. Morooka, M. Norimoto, and T. Kitajima. 1999. Stress Relaxation of Sugi (Cryptomeria japonica D.Don) in Radial Compression under High Temperature Steam. Holforschung $53: 541-546$.

Militz, H., and B. Tjeerdsma. 2007. Heat Treatment of Wood by the PLATO-process. Nordic Wood.

Finnish Thermo Wood Association, 2003. Thermowood Handbook. Helsinki, Finlandia.

Hill, C.A.S. 2006. Wood Modification: Chemical, Thermal and Other Process. John Wiley \& Sons, England.

Inoue, M., M. Norimoto, M. Tanahashi, and R.M. Rowell. 1993. Steam or Heat Fixation of Compressed Wood. Wood and Fiber Sci. 25 (3) : 224-235. 
Koshijima, T. and T. Watanabe. 2003. Association between Lignin and Carbohydrates: Wood and Other Plant Tissues. Springer Series in Wood Science, Springer-Verlag, Berlin, Germany.

Norimoto, M. and J. Gril. 1989. Wood Bending Using Microwave Heating. Journal of Microwave Power and Electromagnetic Energy, 24(4) : 203-212

Srinivasan, N., A.P. Penneru, K. Jayaraman, and D. Bhattacharya. 2006. Value Addition to
Radiata Pine Wood by Thermoforming. In: Yusoff, M.N.M. et al. (ed.). Proceeding of the $8^{\text {th }}$ Pacific Rim Bio-based Composite Symposium. $20-23$ November 2006. Kuala Lumpur Malaysia

Wardhani, I.Y., S. Surjokusumo, Y.S. Hadi, and N. Nugroho. 2006. Penampilan Kayu Kelapa (Cocos nucifera Linn) Bagian Dalam yang Dimampatkan. Jurnal Ilmu dan Teknologi Kayu Tropis, 2(1) : 1-7.

Diterima : 02 September 2008

\section{Suhasman}

Lab. Keteknikan dan Diversifikasi Produk Hasil Hutan

Fakultas Kehutanan, Universitas Hasanuddin

Kampus Tamalanrea, Jl. Perintis Kemerdekaan Km. 10, Makassar 90245

Telp./Fax. 0411-585917. Indonesia

e_mail: suhasman@yahoo.com

\section{Sucahyo Sadiyo}

Lab. Keteknikan Kayu

Departemen Hasil Hutan, Fakultas Kehutanan Institut Pertanian Bogor

\section{Zahrial Coto}

Lab. Kayu Solid

Departemen Hasil Hutan, Fakultas Kehutanan Institut Pertanian Bogor 